\title{
Problems and solutions for assessing the knowledge of students in distance learning
}

\section{Zulfiya PULATOVA ${ }^{1}$}

Specialized Branch of Tashkent State University of Law

\section{ARTICLE INFO}

\section{Article history:}

Received September 2020

Received in revised form 15

September 2020

Accepted 25 September

2020

Available online

1 October 2020

\section{Keywords:}

Digital era

Distance learning

Challenge

Feedback.

\begin{abstract}
To improve the quality of education, the management process distance learning has been built systematically. The concept of a quality assessment system for distance learning presupposes the presence of diagnostic and evaluative procedures implemented by various subjects of state administration entity. It has been delegated separate powers to assess quality of education, as well as a set of organizational structures and normative legal materials ensuring the quality of education. As a rule, assessing tasks with the level of knowledge set quality control helps. It is designed and intended to provide feedback and collect basic information that will allow teachers to judge on the effectiveness of the distance learning process, as well as a system control needs to be developed. Taking into account the basic requirements in this system is imperative. Individuality, consistency, variety of forms and methods, comprehensiveness is considered as key factors. In addition, summative assessment should cover all passed material, objectivity, reliability, trustworthiness and validity.
\end{abstract}

2181-1415/C) 2020 in Science LLC.

This is an open access article under the Attribution 4.0 International (CC BY 4.0) license (https://creativecommons.org/licenses/by/4.0/deed.ru)

\section{Масофавий таълимда талабалар билимини бахолашнинг муаммо ва ечимлари}

\author{
Калит сўзлар: \\ Рақамли давр \\ Масофавий таълим \\ Қийинчилик \\ Фидбек
}

\begin{abstract}
АННОТАЦИЯ
Таълим сифатини ошириш учун бошқарув жараёни масофавий таълим тизимли равишда қурилган. Масофавий таълим учун сифатни бахолаш тизими тушунчаси давлат бошқаруви органларининг турли субъектлари томонидан
\end{abstract}

\footnotetext{
${ }^{1}$ Specialized Branch of Tashkent State University of Law, Senior lecturer of the Department of General education disciplines Tashkent, Uzbekistan e-mail: zulfiya-pulatova79@mail.ru
} 
амалга ошириладиган диагностика ва бахолаш тартибларининг мавжудлигини назарда тутади. Унда таълим сифатини бахолаш бўйича алоқида ваколатлар, шунингдек, таълим сифатини таъминловчи ташкилий тузилмалар ва меъёрий-хуқуқий материаллар тўплами ишлаб чиқилган. Одатда, вазифалар бериш орқали билим даражасини бахолаш сифатни назорат қилишга ёрдам бериши аниқланган. Айнан шу усул ўқитувчиларга масофавий таълим жараёнининг самарадорлиги хақида якуний хулоса имконини берадиган асосий маълумотларга фидбек бериш ва якуний назорат учун мўлжалланган тизим назорати ишлаб чиқилган. Ушбу тизимдаги асосий талабларни хисобга олиш шарт. Индивидуаллик, изчиллик, шакл ва усулларнинг хилма-хиллиги, тушунарлилик асосий омиллар сифатида қаралади. Бундан ташқари, якуний бахолаш барча ўтган материални, объективликни, ишончлиликни, ва адолатлиликни қамраб олиниши мақсадга мувофиқдир

\section{Проблемы и решения оценки знаний студентов в дистанционном образовании}

\author{
Ключевые слова: \\ Цифровая эра \\ Дистанционное обучение \\ Вызов \\ Обратная связь.
}

\begin{abstract}
АННОТАЦИЯ
Для повышения качества образования процесс управления дистанционным обучением был выстроен системно. Концепция системы оценки качества дистанционного обучения предполагает наличие диагностических и оценочных процедур, реализуемых различными субъектами субъекта государственного управления. Были делегированы отдельные полномочия по оценке качества образования, а также комплекс организационных структур и нормативно-правовых материалов, обеспечивающих качество образования. Как правило, оценка задач с заданным уровнем знаний помогает контролю качества. Она разработана и предназначена для обеспечения обратной связи и сбора базовой информации, которая позволит преподавателям судить об эффективности процесса дистанционного обучения, а также должна быть разработана система контроля. Учет основных требований в этой системе является обязательным. В качестве ключевых факторов рассматриваются индивидуальность, системность, разнообразие форм и методов, комплексность. Кроме того, итоговая оценка должна охватывать весь пройденный материал, объективность, достоверность и обоснованность.
\end{abstract}




\section{INTRODUCTION}

Regardless of industrial revolution of high technology and the fast-paced digital era are succeeding in education system, there are still challenges of distance learning to resolve. They might impact negatively both teachers and students in the academic process. Lots of teachers are confronted with challenges and problems which they have not foreseen before. Even though students of this century are born digital communities and many skilled instructors are fairly trained in online platforms, the difficulty of the "distance" can still put forward multiple challenges. Like all other industries, tertiary educations around the world have experienced an almost rapid shift to online learning in an effort to slow the spread of the disease. Multiple challenges have risen, how do a learner and a teacher communicate from a physical classroom to a multi panel Zoom window, how do instructors balance real-time teaching in this type of learning and how do they organize the education process. Assessment in the educational process is the next imperative issue worrying teachers.

Modern platforms of distance learning make it possible to design various types of tests of open and closed type, add illustrations, audio and video materials, conduct testing in control and training mode. If necessary, a self-assessment mechanism can be included in the test tasks implemented on the Moodle platform. In this case, the student gives himself a certain conditional score, which is the degree of confidence in the correctness of the answer. This score is taken into account when establishing the final test score. Online assessment facilitates quick and clear reports on candidate results and progress. This makes it easier to give useful feedback to candidates on how they are doing, areas where they are strong and what areas of learning require attention. Working online makes it easier for the examining body to manage all the tasks involved in creating exams. According to V.S. Avanesov, the objectivity of knowledge control increases with a combination of various test forms: traditional and non-traditional. "A traditional test is a unity of at least three systems: a meaningful system of knowledge described in the language of the discipline being tested; - a formal system of tasks of increasing difficulty [1]; - statistical characteristics of tasks and results of subjects". Non-traditional forms include integrative tests based on checking interdisciplinary knowledge, adaptive tests based on agreement with the student's level of awareness. One of the options for conducting adaptive testing is to use a bank of tasks, divided by difficulty levels. For a student who has firmly mastered the material, there is no need to repeat tasks of the same level many times; it is advisable to transfer it to a more difficult test for him. On the contrary, a student who makes mistakes in answers should be offered material for clarification and assignments for reinforcement. Experience shows that the use of tasks corresponding to the level of preparation significantly increases the accuracy of measurements and minimizes the time for individual testing.

But to be operative in an online environment, the assessments that worked perfectly fine in a face-to-face classroom may need to be twisted or even replaced. Why? Since the distance learning environment presents several challenges comparing with traditional assessment. The following paragraphs will outline a number of challenges of online learners:

1. Necessity of more student-to-instructor collaboration. 
While instructor interaction and feedback are important to all students, it's critical to the success of online learners and-like student-to-student feedback-must be carefully planned and cultivated in an online setting [2]. Fortunately, online tools make incorporating student-to-instructor interaction into assessments relatively achievable through thorough feedback. Strategies for providing rich, detailed feedback vary based on the activities one has selected for his online course. The most practical include building detailed feedback into selected response quizzes; actively managing discussion boards; and administering weekly surveys asking students to identify the concept(s) they're struggling with and then addressing the most-identified concept(s) by using a product such as Jing to create and post quick video clarifications [3]. Indeed, video lessons are handy with their subtitles and they have a great chance to create a reality at least up to $50 \%$ in self-study learning. Moreover, self-check quizzes, online tests are being used to get instant results and outcomes of learners.

2. Lack of interactive materials in online-classes.

Surely, face-to-face classes are lively, visual, qualitative and collaborative. In an online class, however, the amount and quality of visual and interactive materials can vary widely. Internet sources are full of information and one might get anything they wish at any time anywhere. In spite of traditional lessons are based on textbooks, take a multiple-choice quizzes and contact the instructor, they provide more appropriate and productive outcome. In this case the following three assessment ways are beneficial:

3. Greater chance of cheating and harder to detect.

Obviously, online students do cheat more than face-to-face students and it is more challenging to monitor who is submitting the given task and how learners take the test online than it is in a classroom.

Strategies for adapting assessments for online delivery include [4]:

Timed/open book tests. Online, every test is an open-book test (except those that are proctored). To minimize read-as-you-go test-taking, reduce the amount of time students have to take the test so that only those students familiar with the material can answer the questions in the time allotted. Alternatively, replace selected response tests (such as multiple choice and $\mathrm{T} / \mathrm{F}$ ) with short-answer or essay questions that require students to apply textbook facts to novel scenarios.

Shuffled/randomized test questions. Shuffling questions helps reduce the likelihood that two students sitting in adjacent library carrels can take the same test together, one answering the "odds" and the other answering the "evens." Selecting questions randomly from a large test bank takes this idea one step further, providing each student with a similar (but not identical) assessment. (Most learning management systems provide both shuffling and randomization capability.)

Plagiarism detection software. Having students run their essays through a for-fee plagiarism detection service such as Safe Assign or Turn It In can potentially deter cutand-paste plagiarism. At the very least, it can start a conversation about how to cite sources properly.

Frequent low-stakes tests, such as short quizzes or self-check activities worth no more than a few points each, help make cheating more trouble than it's worth. 
Performance assessments. Assignments that require students to write, speak, or present to the class are harder to fake-especially if they occur regularly throughout the course.

Coordinated tests. Instructors who teach multiple sections of the same class may want to coordinate tests so that all students take the same test at the same time. (Staggering tests increases the likelihood that the first students to take the test can pass on question details to their colleagues.)

Proctoring. Requiring students to take proctored exams takes cheating off the table-or, at least, returns it to the same level as a face-to-face class.

At the moment quality is a significant factor in a tough environment competition in all spheres of human activity. Quality is also important in the education system. Therefore, the quality of education is understood as the level of success, socialization of the citizen, as well as the level of conditions mastering the educational program of high educational, and the results that ensure a high level of quality are academic knowledge, social and other competencies, plus social experience acquired by the student in the course of mastering educational program of universities.

\section{CONCLUSION}

It's important to note that while implementation strategies differ in an online environment, the pedagogical strategies underlying assessments shouldn't change when you move a face-to-face course online. Online or off, assessments need to align with course objectives and provide a consistent measurement of student learning [5]. Still, both types stay necessary, educative, and demanding for learners according their learning strategies. As it is known, some grasp information online and some obtain in a lively way. If having students hand-write math proofs so that you can assess understanding and grant partial credit makes sense in a classroom, for example, chances are it makes sense online, too. The pedagogical strategy (hand-written homework) stays the same; only the implementation strategy (having students create and sending handwritten work as a digital file) needs to change [6]. For instance, one may simply photograph sheets of notepaper with his smartphone camera. Transfer these images to the computer through cloud-storage programs like Drop box, Google Drive, or I Cloud, and they can be filed and organized as wished.

Based on the goals of distance learning, parameters have been developed distance learning: logistics, quality educational material, the quality of individual educational programs, quality of individual educational achievements of students, quality self-control and self-assessment systems of students, qualifications teachers and staffing. Each parameter has levels and criteria.

\section{References}

1. Juceviciene P. A. Theory and practice of modular training. [Text] / P. A. Savicheva. - Kaunas: Shviesa, 1989. - 227 p.

2. Vorontsova T.A. Elementary stylistics: teaching and learning resources. Ijevsk Udmurt University, 2009. $130 \mathrm{p}$.

3. Galskova N. D. Modern methods of teaching foreign languages. - Moscow: ARKTI-Glossa, 2000. 165 p. 
4. Giraldo F. The impact of the professional development program on the class of English language teachers' performance. Profile issues of professional development of teachers in 2014. No. 16 (1). Pp. 63-76.

5. Solovova E. N. Methods of teaching foreign languages: basic course of lectures: a guide for students of pedagogical universities and teachers. 2nd ed. Moscow: Prosveshchenie, 2003. $239 \mathrm{p}$.

6. The Cube H. A. practical guide to evaluating English language learners. At the University of Michigan Click. 2013.

7. The Bologna Process and the European Higher Education Area. https://ec.europa.eu/education/policies/higher-education/bologna-process-andeuropean-higher-education-area_en

8. Coombe Ch. A Practical Guide to Assessing English Language Learners. The University of Michigan Press. 2013, 231 p.

9. Vasilyeva M. M., Sinyavskaya E. V. Methods of teaching foreign languages abroad. Moscow: Progress, 1967. 425 p.

10. Ivan Alexandrovich Baudouin de Courtenay. https://ru.wikipedia.org/wiki.

11. Baudouin de Courtenay I.A. Selected works on General linguistics, Moscow: Publishing house of The Academy of Sciences of the USSR, 1963. $384 \mathrm{p}$.

12. https://www.facultyfocus.com/articles/online-education/7-assessmentchallenges-of-moving-your-course-online-solutions/

13. Distance didactic httpproacademy.uz.pdf. 